\title{
Saigon Cinnamon Leaf Oil
}

National Cancer Institute

\section{Source}

National Cancer Institute. Saigon Cinnamon Leaf Oil. NCI Thesaurus. Code C107362.

The essential oil of Cinnamomum loureiroi. Saigon cinnamon leaf oil is used primarily in aromatherapy. 